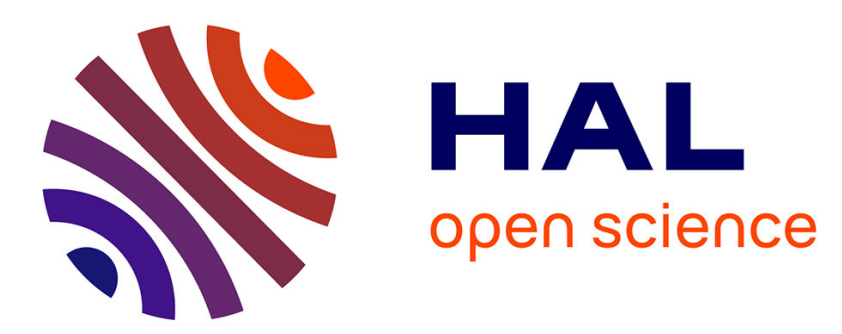

\title{
Surfing on institutions: When temporary actors in organizational fields respond to institutional pressures
}

Amélie Boutinot, Vincent Mangematin

\section{To cite this version:}

Amélie Boutinot, Vincent Mangematin. Surfing on institutions: When temporary actors in organizational fields respond to institutional pressures. European Management Journal, 2013, 31 (6), pp.626-641. 10.1016/j.emj.2013.03.001 . hal-00665213

\section{HAL Id: hal-00665213 \\ http://hal.grenoble-em.com/hal-00665213}

Submitted on 1 Feb 2012

HAL is a multi-disciplinary open access archive for the deposit and dissemination of scientific research documents, whether they are published or not. The documents may come from teaching and research institutions in France or abroad, or from public or private research centers.
L'archive ouverte pluridisciplinaire HAL, est destinée au dépôt et à la diffusion de documents scientifiques de niveau recherche, publiés ou non, émanant des établissements d'enseignement et de recherche français ou étrangers, des laboratoires publics ou privés. 


\title{
TEMPORARY ACTORS IN AN ORGANIZATIONAL FIELD: HOW DO THEY REACT TO INSTITUTIONAL PRESSURES?
}

\author{
Amélie Boutinot ${ }^{1}$ \\ Vincent Mangematin ${ }^{2}$ \\ Grenoble Ecole de Management
}

\begin{abstract}
Institutional scholars focus on practices and behaviors of actors permanently belonging to an organizational field - but what about organizations that are new and only temporary in such a field? How do they react to the field's institutional constraints? Based on an in-depth analysis of the architectural contest for QuikSilverRossignol's new European headquarters, this paper introduces the idea that such actors, who connect to a field only temporarily, may not conform to or change such institutional pressure, but may rather 'surf' on institutions, adopting but adapting their rules in ways that do not lead to bricolage, institutional change or translation. Introducing the notion of 'surfing on institution' allows us to complement the literature on organizations' responses to institutional pressures and norms.
\end{abstract}

Keywords: Institution; Temporariness; Organizational field; Architecture

\footnotetext{
${ }^{1}$ Corresponding author: Grenoble Ecole de Management, 12 rue Pierre Sémard, 38003 Grenoble Cedex 01 ; amelieboutinot@gmail.com

2 Grenoble Ecole de Management, 12 rue Pierre Sémard, 38003 Grenoble Cedex 01
} 
"The documents we receive [from architects] during a competition are very administrative. This would be acceptable if it wasn't for the nit-picking technical regulations that oblige the contest to conform to an official procedure. Apart for the difficulties this causes the architects, we are anxious about the lack of democratic debate about public building. We need to make the architectural competition really significant ... it needs to be more than just a strict procedure".

[President, Regional Ordre des Architectes, France, 2008]

\section{INTRODUCTION}

Imagine some surfers on a beach, running towards a big wave. They live this moment intensely, because they occasionally enter in contact with the wave, which both gives them the energy to move and orientates their trajectory. Indeed, surfers have to draw on the wave to surf, but they cannot go anywhere they want, they cannot move against the flow. The topic of this paper builds on this situation, to study how actors deal with pressure in an environment with which they are only occasionally in contact.

Organizational fields are stable social spaces, where interactions among members are frequent, routinized (DiMaggio and Powell, 1983; Scott, 2001). We differentiate between permanent field members, who shape the field, the interactions among its members and its institutions (defined by Scott as "regulative, normative and cultural-cognitive elements that, together with associated activities and resources, provide stability and meaning to social life"), and field members who only interact with the field only once or for short periods. Permanent members of the field fight for their ideas, shape the field, and face strong constraining pressures from their environment. They engage in political dialogue with its institutions with the aim of gaining legitimacy (DiMaggio, 1988; Hwang and Powell, 2005; Garud and Karnøe, 2003), as well as in institutional change and entrepreneurship (Barley and Tolbert, 97; Battilana, 2006; Lawrence and Suddaby, 2006; Symon and Buering, 2008; Wijen 
and Ansari, 2007). Those who interact temporarily with a field (Hoffman 1999) have to work within its existing institutions, as they also face their pressure (Zucker, 1977); but they may react differently to them. Therefore, few of the previous models of reactions to pressures address the question of how actors that only join such fields for a limited period deal with its pressures.

When Quiksilver bought the Rossignol ski brand in March $2005^{1}$, the top management of the new QuiksilverRossignol (QSR) decided to build a new European headquarters for Rossignol. QSR adopted the architectural contest procedure, an institutionalized procedure within its field, because the company considered it would be the best tool to choose the most appropriate architect. We consider QSR - the client - as a temporary member in the architectural field, and the architectural contest, which represents an explicit norm of the architectural field, as a normative institution (Scott, 2001). As we shall see, although QSR adopted the formal architectural contest structure, it also adapted it to make both its process and results more useful from its perspective. We call this reaction "surfing" on institutions. Using the neo-institutional lens helps us state the institutional pressures in this field while improving our understanding of how temporary field members may react to them. While our study does not deal with institutional change (Dacin et al., 2002; Kraatz et al., 2002) or translation (Zilber, 2006), it may still have three potential implications for institutional theory. First, we better understand the range of possible reactions to neoinstitutional pressures by addressing those of temporary field members. Second, this study refines the notion of field membership (DiMaggio, 1991; DiMaggio and Powell, 1983; Hoffman and Wooten, 2008; Phillips, Lawrence and Hardy, 2000) by distinguishing between 'home' and 'host' fields. Finally, this study discusses the role of temporary members within a field.

The paper is divided into six parts. The first presents the theoretical basis underpinning our research into how permanent actors behave in the face of institutional pressures and what sort 
of organizations might be field temporary members. The second section details the method we used to gather and make sense of our case study information. The empirical context of our research is described in the third part, and the fourth presents our case study. The fifth section introduces three findings of specific interest, while the final section includes a discussion on the implications for institutional theory of 'surfing on institutions', and some directions for future research.

\section{THEORETICAL BACKGROUND}

\subsection{Permanent field actors and the institutional pressure for conformity}

Neo-institutional scholars define organizational fields as 'sets of organizations that, in the aggregate, constitute a recognized area of institutional life: key suppliers, resource and product consumers, regulatory agencies and other organizations that produce similar services or products' (DiMaggio and Powell, 1983: 148), where diverse profiles of members interact frequently and productively (Scott, 2001). These interactions, which link actors and define their actions vis-à-vis one another (Fligstein, 1997), create the field's coherence and its common logics (Thornton and Ocasio, 1999; Seo and Creed, 2002). Where such interactions are stable and routinized (Greenwood and Suddaby, 2006), and the field's structure, logics, members' positions and practices remain stable over time, the field can be considered as highly institutionalized. Compared to emerging fields where logics and rules are less established, members in such fields have a mutual awareness of who belongs to this space i.e. those who are permanently and stably attached to its activity - and who doesn't. In this article, we call 'permanent' actors those who are involved in a field over time.

The stability of a field's structure is mostly guaranteed by its institutions - the sets of rules, norms, schemas and cultural beliefs that organize its social life (Zucker, 1977; Hodgson and 
Jiang, 2007). Compared to emerging fields, where actions are mostly uncoordinated, institutions in more mature fields are largely diffused and accepted by field members (Hoffman, 1999), and so can be perceived as strict guidelines, as enduring elements that profoundly affect the thoughts and behaviors of all the field members, akin to habits (Berger and Luckman, 1966), routines (Scott, 2001) or stable landmarks (Zucker, 1977).

Permanent organizations in a field are particularly impacted by the field's institutions, because they wish to acquire, maintain or extend legitimacy in their field (DiMaggio and Powell, 1983; Hoffman, 1999; Scott, 2001). Legitimacy has been seen as a the "generalized perception or assumption that the actions of an entity are desirable, proper or appropriate within some socially constructed system of norms, values, beliefs” (Suchman, 1995: 574), which is necessary to obtain recognition and be dominant within this space. Permanent field members use institutions to compete for domination over the others (Battilana, 2006; Bourdieu, 1990; Bourdieu and Wacquant, 1992).

To do so, neoinstitutional scholars have previously showed how field members may react to its institutional pressures, especially applicable when they are permanent within such field. Oliver (1991) studied such reactions, which ranged from accepting field institutions and conforming to their norms and values, leading to isomorphism (DiMaggio and Powell, 1983); attempting to reach compromises designed to lessen the constraints of institutional rules and internal conditions (leading to decoupling - Boiral, 2003; Elsbach and Sutton, 1992; Meyer and Rowan, 1977; Whestphal and Zajac, 1994, 2001); or to manipulating or even defying existing institutions, leading to institutional change (Kraatz and Moore, 2002; Seo and Creed, 2002; Dacin, Goodstein and Scott, 2002), or even to deinstitutionalization (Oliver, 1992). In their study about emissions trading, Pinkse and Kolk suggested other scenarios to institutional constraints (2007): field members facing strong constraints can be institutional conformists (when they expect to be constrained by the institution but abide by it as there are no 
opportunities in changing it) or entrepreneurs (when they expect to be constrained by an institution and decide to change it in a way that serves their own interests).

In fact, it seems permanent field members act in ways that either respect and support field institutions, or seek to challenge and change them. But field membership can also be for a limited period (Hoffman, 1999): actors can temporarily enter a field, without acting like its regular members. We draw on Zilber (2002) and Goodrick and Salancik (1996) - who noted that a field's institutions do not necessarily affected all its members in the same way, nor (as Greenwood and Hinings, 1996, point out) are they exposed to institutional pressures to the same intensity - to suggest that organizations only temporarily connected to a field may not react the same way as permanent members do. As a consequence, the predictive power of previous models seems to have been quite low in terms of specifying responses to institutional pressures by new and temporary members, as they may not face pressures like permanent members do.

\subsection{Temporary actors}

As previously mentioned, a field's structure and order are generally established, and permanent members, who have been connected to it over some time, are highly impacted by its institutions. In contrast, new entrants that are not as involved in the field interactions and routines, and are only briefly connected to a field, may not react the same way. Such actors will be called here 'temporary' members of a field.

Our focus on this specific type of actor introduces the concept of temporariness as a new dimension in understanding the range of actors' attitudes to their fields and to institutional pressures. Temporary organizations, whose interaction with a field is short and disengaged, act in a 'one-shot' fashion and for a specific reason (for instance, consuming a product just once, establishing a short-term partnership with a field member), and leave when the 
relationship has outlived its usefulness. They may have no political strategy aimed at modifying the field's institutions or established order, and may not see any recognition opportunity in challenging the existing institutions. They are thus generally considered as institutionally less constrained: even if they are subject to this field's institutional pressures (Zucker, 1977), they may face them with less intensity (Greenwood and Hinings, 1996; Leblebici et al, 1991) compared to permanent actors.

Concerning their reactions, they may neither be interested in institutional change nor any of a field permanent members' reactions described by Oliver (1991), nor in operating a translation - to modify the established order to institutionalize new meanings (Zilber, 2006). Pinkse and Kolk, in their 2007 study, presented some reactions for members facing weak institutional constraints, a situation that can be applied to temporary field members: such members can be institutional evaders (under weak pressures, they may see no clear opportunity neither to conform to or change the institution) or arbitrageurs (under weak pressure, they may see some opportunity to build entirely new institutions for their own interest). But we have to see if such behaviours are also applicable to temporary field members.

As a consequence, a field's temporary members may not react as previously suggested by institutional scholars. Temporary field members therefore represent an interesting axis of research to improve our understanding of actors' reactions to institutions and field membership. We propose to investigate this gap via an exploratory case study which will shed light on the following research question: How do field's new and temporary entrants react to its institutional pressures? 


\section{Methodology}

\subsection{Research design}

To study how new and temporary entrants in a field react to its existing institutions, the research design requires a specific situation: a close relationship with permanent and temporary field members.

The case under review is the process by which QuiksilverRossignol (QSR), in conducting an architectural competition between mid 2005 and May 2006 to choose an architect for its new headquarters, reacted to the procedural pressures of that field institution. This is a thus critical case (Yin, 2003), in which the unknown process of how a temporary actor reacts to the institutional pressures of a field may be unfolding more evidently. To select this case, we first selected architecture as a context, as it can be understood as an organizational field (DiMaggio and Powell, 1983), as a space within which various actors - architects, actual or potential clients, and legal authorities - can interact. We then identified some private clients temporary companies - French or international - that had that entered the French architecture field for limited-time interactions, and finally selected the one that was recent, that had received enough media coverage to be traced accurately, and that showed more intensively their expectations and desires for a quality project, so as to be able to see more clearly how an organization entering a field for a short time reacted to one of its most important institution. The QuikSilverRossignol architectural competition in 2005 corresponds to those criteria, and especially the last one. QSR had a very specific motivation. First, the competition for the new Rossignol headquarters takes place in a specific context. Having bought Rossignol, QSR needed to upgrade the image of the French brand (which has been declining over recent years) and determined that having a 'superior' building will help. While LVMH (for instance) might need a headquarters that is gorgeous, QSR needs one that will embody the image of sports, innovation and dynamism it want to put across as part of its aim to renew Rossignol's brand's 
image. QSR is also a private 'one-off' client, so the context differs from that of a contest for a public building, where the state or local authority (as permanent clients) cannot depart from the established rules they habitually follow in such contests.

\subsection{Data collection}

Two types of material were collected. First, to avoid biased selectivity, all available documents about the contest were collected from all the actors involved in the competition and reviewed: documents from the four competing architects (their architectural concepts, their various proposals, sketches, sections, plans, etc., their exchanges with their engineering team and meeting reports, as well as emails and messages between agency and QSR), QSR documents (the preparation of the contest program, the assessment grid recording the competing architects' rankings after each meeting, and emails and messages within the strategic committee and between them and other contest participants). Second, we conducted a set of interviews with the contest participants to help us understand their feelings and experiences, from which we gathered information about the procedure, the relations between the actors, how architects dealt with the rules, and learnt about other elements not stated in the documents. We interviewed the winning architects (I. Herault and Y. Arnod) on a bimonthly schedule between July 2006 and May 2007. The two first interviews were fairly unstructured, because we wanted to make the discussions as free as possible to find out about the project from their perspective. Later interviews were more detailed, with a semi-guided questionnaire designed to gain factual information about specific elements of the contest we needed to understand better. We also interviewed the other architects invited to the contest $-\mathrm{C}$. Vasconi, B. Delagarde and M. Sliwa (Sud Architectes) and P. Arotcharen - for an hour and a half each between February and May 2007, with semi-guided questions built into the interviews, to understand how and why QuiksilverRossignol contacted them, how they developed their architectural proposals for the headquarters, how they managed the competition and how they 
felt the architectural contest rules affected their ability to do their job. Finally, we interviewed the members of the architectural contest's strategic committee (T. Miremont, QSR Senior VP for Business Development, J. F. Gautier, President of the Rossignol Board of Management; Y. Barnoud, Rossignol Administrative and Financial Director, and A. Prochilo-Dupont, who was in charge of the economic development at the local Pays Voironnais region) about the creation process and their role in the transformation of the contest ${ }^{2}$.

\subsection{Data analysis}

First of all, to analyze the different narrations and to identify how QSR modified the contest process, we decomposed the architectural process in three phases: the adoption of its general framework; its adaptation by importing rules from another field; and finally its adaptation to QSR's choice of its desired architectural partner. We followed Langley's temporary bracketing methodology (1999) for this process, decomposing the data into phases, as a way of structuring our description of events into a chronology to help us synthesize information and extract the most relevant elements about how QSR reacted to the constraints of the architectural competition format. By comparing step by step what should have been done (according to the official procedure of the architectural contest 'institution' - Daly, 1861; Le Moniteur, 2004; Le Moniteur, 2007) with what was actually done in this case, we identified which elements QSR questioned at each stage, how they dealt with them, and what benefits they gained by altering them. The case study text recounts the contest's phases and describes QSR's reaction to its procedural demands, using specific narrative techniques (Chiles et al., 2004) to present a rich and eventful single case study.

\section{FRENCH ARCHITECTURE AS A HIGHLY INSTITUTIONALIZED FIELD}

The entity 'French architecture' takes in every organization based in France involved in the construction of a new building or a refurbishment - architects, clients, legal authorities, etc.. 
Since the 1980s the profession has been connected to international standards, so that French architects not only exercising their talents nationally but also internationally, participating in international competitions and designing builds worldwide. Such an arena makes an interesting context for this study, both because some of the theoretical points noted above are clearly visible (Yin, 2003), but also because, while the French context gives the case some specific elements, the integration of French architectural practice into international standards helps its generalization to global architectural contexts.

French architecture is a good opportunity to study our research question, as it can be understood as an organizational field. First, French architecture is a domain of activity comprising members of several profiles (architects, clients, legal authorities, among others), who interact frequently to make new buildings or refurbishments. This frequent interaction is coordinated by various norms and schemas, such as national and international annual awards (such as the Pritzker Prize, awarded to two French architects since its creation) and architectural contests $^{3}$ that make the arena institutionally and coherently organized. More specifically, actors' behaviors are routinized and structured around the architectural contest, which acts as a meeting point where the field's different actors interact regularly: every time the French government, cities or municipalities need new buildings or refurbishments, or when a private firm like LVMH wants a new headquarters, an architectural contest is organized. As a consequence, each profile in the field has had its roles defined and stabilized since the 1980s: architects create and make buildings to answer societal needs, clients order and pay for those new buildings, and professional bodies such as the Ordre des Architectes regulate the actors' interactions.

Second, architects and public clients (government, cities, municipalities...) interact regularly in the French architectural field. Architects seek legitimacy in the field, and compete with each other to become the new important builders. Public clients regularly ask for new public 
buildings (schools, museums, housing ...) and organize architectural competitions to hire the best architect for their projects, and so they can be considered as field permanent actors. In contrast, private clients are considered as temporary in the French architecture field companies such as QuikSilverRossignol will only interact once (perhaps twice) with architects, to build their new headquarters, offices or labs. Such clients come from their own organizational fields (finance, sportswear, scientific research), and will have in mind their own institutions. Their time-limited interaction with architects may be made more complex by the fact that they do not work together regularly - for what is taken for granted within a field is not considered as acceptable in the other one. For example, QSR manages its suppliers via invitation to tender, where submitters are not paid to submit - but, in an architectural contest, invited architects are paid a fixed fee for their participation. As permanent members of the French architecture field, public clients respect the procedure of the contest strictly, as a compulsory routine (following the acceptance strategy described in Oliver's 1991 study) - but temporary clients may be surprised by these practices - from an unfamiliar organizational field - and try to adapt them.

In this article, we specifically focus on the architectural contest, because it appears as the most important mechanism for organizing interactions between members of the French architecture field, where its well-established procedure is considered as a normative institution (Scott, 2001: 148) which is both highly diffused, and is compulsory, among both architects and public clients. It is an official and explicit written procedure, backed by legal mechanisms and authority, which prescribes what participants on both sides must (and must not) do. It is compulsory for public clients, and is highly recommended for private contractors. This represents a weak pressure for them, but they still have to face it. And if they decide to adopt it, they are obliged by law to respect the same procedure as a public client. At root, the procedure is designed to protect the interests of both sides, enabling architects to do their job 
under the best conditions and clients (who will not, normally, be experts in the field) to have a procedure to guide them, and on which they can rely.

The architecture contest is a strict and inflexible guideline, and advocates a legal and moral commitment that has to be fully respected. The contest rules define, in formal terms, how the competition is set up, making things predictable for both sides: it provides a guide for the process and for a strategic client committee to supervise the competition and select the best architect, and stipulates the specific elements to be delivered by participating architects in contracts signed by all parties at the outset. It is subject to national authority (the Government Contract Code), to professional bodies such as l'Ordre des Architectes, and to European directives. Its provisions are legally enforceable, so that actors failing to conform to the contest procedure face penalties: architects risk being considered negligent (Winch and Schneider, 1993), and both sides can appeal to the Code Commissioner or the Ordre des Architectes to stop the process and to the Administrative Court to impose penalties on the non-conforming party.

\section{QSR: A TEMPORARY ACTOR IN THE FRENCH ARCHITECTURE FiELD}

'Besides wanting to build commercial synergies with Rossignol, QSR wants to revive the French brand and develop it into a powerful identity' (QSR President in 2006).

When QuikSilver buys Rossignol in March 2005, it aims to integrate the French ski brand to become No. 1 in the global outdoor market. According its Senior Vice President Business Development (T. Miremont) QuikSilver has three objectives: first, to reorganize Rossignol's geographical location to house all its employees (management, $\mathrm{R} \& \mathrm{D}$, production staff and

administrative teams) in one building; second to spread its management culture across into Rossignol: 'the building will make Rossignol's management culture younger and more 
international - a new site for a new brand'; and finally, that the proximity of its several departments should encourage more direct and fruitful relationships between them. So Rossignol's future headquarters is to be designed in line with these objectives and located near Grenoble, a dynamic economic area very close to the French Alps which is also the birthplace of Albert Rossignol, the firm's founder. We articulate the presentation of the contest around three main phases: the adoption of the architectural contest by QSR; the importation of rules from another field; and finally the adaptation of the contest to be able to choose which architect QSR most wants to work with.

\subsection{Phase 1: Adopting but questioning the architectural contest's rules}

QSR decided to adopt the contest procedure not because it was strongly constrained to do so, but because they saw an opportunity to assure the company of a coherent and planned progression to their search. Moreover, they consider the procedure the best way to attract well-known architects and 'to make ideas and projects compete. We wanted to challenge their talents' (Committee member). Once QSR has adopted the contest procedure, its researches show that architectural contests always follow an established set of rules to guide the selection of the best architectural proposal. These include anonymity (the contracting client will not meet or dialogue with the competing architects); stability of composition of the strategic committee that will assess the architectural projects; a fixed time length (less than 6 months); requirements on the client to produce a precise specification for the building's required characteristics and the budget that needs to be met (here called "program"); the fixed composition of the set of documents (plans, sketches and explanatory notes about the proposed building design) the competing architects must deliver to the strategic committee ; a formal opening of the architects' proposal envelopes and ranking of their projects based on 
the documents they have supplied; and a guaranteed fixed fee (about $€ 30,000)$ to the architects participating in the competition.

QSR follows several of these points to the letter, judging that '[this] will help us manage the competition: In April 2005, it establishes a strategic committee which will manage the contest and select the competing architects, and issue the calls for tender defining the contest program. As dictated by the official procedure, it is to be composed of several competences: T. Miremont (from Quiksilver) and Y. Barnoud (from Rossignol) manage the project's financial and brand identity aspects respectively; A. Prochilo-Dupont (from the Pays Voironnais local authority) is to take care of legislative matters and QSR's interactions with local and regional public bodies; G. Giacometti (from Duo, the local town-planning architectural agency), who suggests which architects are to be invited and gives the committee architectural advice. QSR members manage the committee and take the final decisions, even if 'all the decisions were taken in a nice debating atmosphere, where everyone listened to each other' (J.F. Gauthier).

QSR also writes the program as required by the official contest procedure. First, it presents its aims for the new building in terms of values and identity following the rationale noted above: the headquarters are to comprise offices, a machine floor (to coordinate the production of prototypes with manufacturing), and public spaces including a showroom, a restaurant, a sports room and a ski museum. QSR wants the building to combine tradition and modernity, to embody both Rossignol's mountain roots and a sense of innovativeness, and finally to be evolutionary. Second, it outlines the step-by-step schedule for the contest and details the timescales involved: the committee is to send the program to the competing architects by 18 th Nov 2005, and they must return their proposals by 6th Jan 2006: their envelopes will be opened the next day, and the committee is to select the winning architect during the following week. Third, the committee details the elements it expects from the architects, which again are 
standard: their proposal of and building sketch expressing their architectural concept, accompanied by plans and technical sections ${ }^{4}$; a calendar showing the proposed building schedule; a budget estimate; an architectural note to clarify the suggested concept; a display to illustrate it and to detail the shape of the building and any elements the architects particularly want to highlight about their project; and finally details of the engineers each architect proposes working with. The program specifies that the selection criteria will focus on the quality of the adaptation of the building to the landscape, its ecological strategy, the suitability of the design to the client's needs, and how the proposals measure up to specific functional, technical feasibility and overall cost demands. The program also suggests that the building should be reusable for other industries, were QSR to want to sell it.

QSR knows it is not supposed to modify the procedure after having adopting it without risking being penalized. But as the company feels poorly constrained and sees a clear opportunity to improve the results by modifying the procedure, it decides to skirt some of its official elements around. In contrast to public contracting clients (who may question the procedure but are used to respecting it) a private client who doesn't approve some of the points can decide to adapt them, 'as they are irrelevant, more constraining than helping the project' (QSR committee member). The alterations are carefully and opportunistically made to improve the relevance of the contest to QSR's objectives, but without modifying the procedure too much to risk being penalized. They tested some modifications on the architects, who kept on accepting them.

First, QSR leaves the specifications of the future headquarters incomplete, especially in terms of the general look and feel of the building, and of the final budget. As in its handling of industrial projects, QSR decides to leave the expertise to those with experience, and writes the program in such a way as to give the architects carte blanche as to their architectural concepts. 
It wants the architects to have as much room to maneuver as possible, so they feel free to suggest relevant or novel ideas, reasoning that this will improve the quality of their project proposals. And second, QSR's top management wants to arrange to meet the competing architects. When it manages its industrial projects, the company arranges to meet good potential partners so that it can select the best on financial, technical and human criteria. So the company decides to break the anonymity rule, and schedules a meeting into the program for direct dialogue between client and architects during the week of 9th Jan 2006. Although these alterations modify some of its procedures, the contest's general structure and coherence are maintained, and QSR does not risk losing the certainty and predictability of the contest's progress.

\subsection{Phase 2: Challenging the architectural contest by importing rules from another field}

QSR sends a formal contract to the four architects its committee has chosen, making the rules of the game explicit; the architects accept and sign the contract: 'The program was very interesting because we were really consulted to give our opinion about what the building should express; there were key notions that were not constraining our creativity' (B. Delagarde). So each architect must choose to highlight in their design the elements they judge as most crucial for the client, taking the risk of leaving other elements specified by the client as secondary in their project proposal.

The Herault-Arnod architects decide to focus on Rossignol's values, and work on a concept that combines technicality, fluidity and nature, creating an organic building that is 'adapted to the contours of the mountain'. The building will gather all the company departments with a view to making people work together, but without being a high-rise 'office block'. The roofshape is designed to allow the building to 'fit' into its mountain landscape, respecting the essence of natural shapes in an architectural concept Herault Arnod described as a landscape under snow'. 
Vasconi (the second architect) considers that Rossignol's activity was 'based on modernity (the ski competition, the technical excellence) and respect for nature (setting the activity and the building within the landscape)', and develops an architectural concept focused on the two notions of modernity and ecology. He judges the aspect of making people work together less important and so does not emphasize in his proposal. He decides to give his shape modernity by designing three adjoining buildings, with white metallic roofs and using the crystalline effect of glass. Natural materials (essentially wood and stone) are to be used to emphasise the ecology element, and the roof is shaped like a ski-run, fitting the shape of the building into the mountain landscape. Detailed landscaping around the building is designed to highlight the importance of the natural environmental setting.

The third contestant, Sud Architectes, decides to base its response on the possible repurchase of the building, rather than creating a concept based around gathering the client firm's departments together. The design is therefore focused on modularity and proposes a divisible space concept that could house about 20 SMEs if Rossignol were to leave. The architects aim to evoke fluidity and dynamism in relation to technology, and focus on mountain elements, suggesting the use of related materials such as gabion ${ }^{5}$, together with wood and aluminium to evoke both the mountain spirit and a sense of Rossignol's activity.

The final contestant, P. Arotcharen, decides the modularity aspect is less important, choosing to emphasize instead the importance of making people work together, and thus focuses on the internal organization of the building. He also explores the mineral aspect, and seeks to echo the outdoor experience in the building's interior: 'We didn't want to focus the mountain references on skiing; we used outdoor and mineral elements, such as rock to try to express the excitement one feels in front of the impressiveness of vast landscapes. Quiksliver enshrines such values - and we are used to them'. To express the notions of minerals and the outdoors, he proposes using rocky materials through the whole concept - but not snow, because 
'mountains don't always mean snow, and they don't always mean skiing'. His design proposes organizing the interior of the building as a sort of fitness trail: people working in the building will be able to have excitement of walking on rocky ground, watching the services from interior balconies, and feeling the effects of nature even while inside the building.

After the architects deliver their four different interpretations to the committee (in the documentary form required by the program, as stipulated in the contract), the contest procedure next involves the committee opening the architects' submissions and considering their proposal documents in a first round of meetings. For this purpose, QSR again modifies the contest rules by temporarily increasing the size of the committee. The company feels it is very important to have a wider range of people - including those who will be using the building - to complement the committee's reactions, so Rossignol executives and directors of several departments and staff delegates join the group so it has 'a mix of competencies and sensibilities for our first impression of the projects' (QSR committee member). The proposal envelopes are finally opened, and the meeting with the four architects and their technical teams (who cover the structure of the building, exterior plans, and all the necessary technical aspects behind the future building's success) takes place a few days later, giving the architects the chance to flesh out their concepts.

After this, the contest should have stopped and the committee selected the winner. But the committee finds ranking the projects very difficult - all four are interesting but none is fully convincing. Although the contest rules do not authorize such a step, QSR decides to keep the competition alive: it motivates the whole committee to give the architects the chance to improve on their first suggestions, justifying this move as 'a good way to improve the choices'. The architects all accept this suggestion: 'QSR's process stimulated us more than if they used the rigid procedure, where everything is muzzled' (B. Delagarde, Sud Architectes); 
'Architects rarely have the chance to negotiate with those who have to make the final decision' (I. Herault); 'the project was interesting - it kept challenging our architectural abilities', (C. Vasconi). They also know these modifications will only apply to this project, so the official contest procedure is not being challenged. The contest timetable is changed again, and the procedure begins to look more like a tournament.

Once again, this change mirrors the way QSR acts in managing its own activities - when it not sure, it extended the decision-making process to enable people to have more discussion about problems and improve the quality of the solutions they propose.

The four architects are invited to represent their concepts in front of the official committee. After this second presentation, in February 2006, the client still has to deliberate and come to a final ranking of the projects. It decides that neither Vasconi's nor Sud Architectes' concepts match its needs well enough: QSR feels that Vasconi 'had neither created a building specific to the Alps nor to a ski brand; it could have been any high-tech firm headquarters'. Sud Architectes' approach was also seen as void: 'The project didn't match up to our specifications .... It was valueless for our firm'. Both losing practices accept the decision without seeking to complain about the client's procedural changes: 'QSR offered an interesting challenge; our answer did not match its hopes, but it was worth participating...' (Sud Architectes).

\subsection{Phase 3: Adapting the institution to decide who to work with}

But QSR doesn't just want to buy a good building; it also wants to have a good relationship with its architect. QSR still cannot choose which of the two remaining architects - Herault Arnod and Arotcharen - should build the new headquarters. But, rather than simply having a further meeting to make its choice, it proposes extending the contest to another round, and both agencies decide to stay in the extended competition. Now, QSR wants to be sure they can deliver on their promises: it wants the committee to learn more about the architects. As in 
its industrial projects, QSR wants to know who it is going to work with, in human terms - so, once again, it adapts the official procedure to make the contest relevant to its expectations, based on its project management practice, where every unclear point is resolved before decisions are taken. But QSR learns from its previous changes, so it compares the projects to sharpen its analysis and its thoughts. Once again, the architects understand that the procedure is only being modified for this specific project, and that these modifications will help the client make the best decision, so they accept the committee's ideas. This new step will give the architects a final chance to improve their presentations, only this time the theme of the debate will change. The final meeting (planned for 23rd May) will be where they can show that they really appreciate what the client wants, and to find out if the two sides can communicate effectively. So the two remaining architects make further preparations to convince the client at this final meeting.

The Arotcharen practice feels its communications to date have been insufficiently in tune with the committee's expectations, and this final meeting gives the agency a chance to give a more articulate presentation of its proposal. It produces a brochure to summarize its architectural concept, the functionality of the building and the value of the design to Rossignol, and makes a model to allow the client to 'see' the building in a more concrete way. 'Although it was a bit abstract, the model it expressed our concept for the building very well' ( $P$. Arotcharen).

For its part, the Herault Arnod agency feels the sketches its has presented so far have been too 'cold', and did not represent the welcome QSR hoped for in its new Rossignol HQ, so it decides to present final modifications to its building in the form of a small book, presenting warmer building interior pictures: 'Yves and I decided to make a booklet with a good quality paper, like we use for watercolors, where we put some pictures speaking of a welcoming setting .... People around a chimney fire, at dusk, with warm colors - red, orange and brown' (I. Herault). 
After more than six months of contest and tournament, in May 2006, QSR decides to appoint the Herault Arnod agency as the official architect for Rossignol's European headquarters: 'The Herault Arnod agency won the contest because they put themselves in our staff's place. They also demonstrated they were motivated to work with us as clients' (A. Prochilo-Dupont).

\section{FINDINGS}

The architectural contest allows us to understand how actors who enter a field only temporarily react to its institutional pressures. Our case reveals that QSR, as a new and temporary member of the architectural field, reacts to the weak constraints by adopting but adapting the architectural competition institution. QSR seems to be neither an evader nor an arbitrageur: we therefore suggest answering our research question thanks to what we call 'surfing on an institution'.

First of all, our case reveals that QSR follows neither an evader nor arbitrageur strategy. Indeed, contrary to an evader, who is weakly constrained by institutions, but does not see either any clear opportunity to change the institution, QSR did modify the rules of the game for the competition it organized. But contrary to an arbitrageur, who also faces weak constraints but creates a entire new institution to strategically gain from it (Pinkse and Kolk, 2007), QSR did not create a new contest procedure. It only altered some of its elements for this specific headquarters project.

As a consequence, we suggest QSR answers the French architecture field pressure by adopting but adapting its main institution for its own case. We call this new answer "surfing" on institutions. We explain this in the following lines.

Surfing on an institution echoes surfing on a wave: Surfing on institutions can be understood as 'opportunistically drawing on' the rules of the field. This notion has been 
inspired by the action of surfing a wave: surfers draw on the wave, which both gives them the energy to move and orientates the movement - you cannot surf against the flow. The wave does not entirely constrain surfers, who slightly draw on the momentum of the wave to move along the trajectory they desire. Surfing on institutions is similar: the direction and the general pattern are given by the institution (the wave) which imparts the force of the organizational field, channeling the energy of actors in one direction.

Surfing on institutions as opportunistically drawing on the wave: QSR opportunistically draws on the architectural contest. New and temporary members' participation in a field is weakly constrained but can gain from its institution as surfers can gain from the wave's energy. As a temporary participant, QSR adopts the architectural contest as a general explicit norm not due to conformity high pressures, but as a relevant tool to help it achieve the best solution for its new headquarters. While keeping to the framework of the contest, to allow it to plan project's development, the company does not hesitate to alter some of its elements, such as anonymity, to align better with its objectives. The modifications allow QSR - the surfer - to 'lean' on the contest's existing force to improve the architect's' proposals, and to achieve the building (and the working relationship) it really wants. As a temporary member, and even if it faces the institutional pressures, QSR pays less regard to these field habits, and so can initiate more easily modifications while still avoiding being penalized (either by the architects refusing to continue participating, or by any authority or judicial process).

Surfing on institutions, as opportunistically and temporarily distorting the rules: The contest predicts what is going to happen; QSR "leans" on these existing rules but just modifies how and when it happens. QSR could alter how and when the several elements of the contest were going to happen because for their part, the architects, as permanent actors of the French architecture field, see such modifications to their field norms as being both wise and relevant - because they still respect their work and talent - and appreciate how altered 
institution enables temporary members to manage their path and project in the field more successfully. Contrary to ideas of institutional change (Dacin et al., 2002; Kraatz et al., 2002) or of translation (Zilber, 2006) - the modifications to the institution are not aimed at breaking it. QSR only wanted to modify the contest to improve the process and the result in its own case - it had no desire for political strategy aimed at dominating permanent architecture field actors.

\section{Surfing on institution, as a combination of the surfer's energy and the wave energy:} Surfing on a wave both implies the wave's energy and the surfer's one, combining the two. Like a surfer who leans on the wave's force, surfing involves temporary field members making alterations that may combine logics from different fields, and that these may cross these fields' boundaries. We draw on Meyer and Rowan (1977) and Johnson, Smith and Codling (2000) to highlight how new and temporary organizations 'import' knowledge from their own fields and combine it with their temporary 'foreign' field setting. In this case, QSR manages the architectural contest by drawing on the architectural contest procedure, but also importing some habits from its industrial practice to replace elements of procedure it found constraining - such as organizing meetings to meet the 'suppliers' - allowing the architects carte blanche to come up with their original ideas and giving them opportunities to refine those ideas in the light of client feedback. import from its field and mixes with eth architecture field. Where access to resources might be a problem in a case of institutional change (Garud et al., 2002), surfing on an existing institution can allow the temporary organization to call on knowledge, capabilities and experience it already has.

Surfing on institutions, as being temporarily connected to a wave: the case reveals how surfing is related to temporariness in an established field. The field's structure is so stable that its permanent members of more constrained by routines and collective habits - they may question them, but still feel obliged to follow their procedures to the letter. Indeed, QSR, and 
not the competing architects, initiates the modifications to the procedure. The four architects respect the rules of the game perfectly, as the contest protects their interests as professionals. We explain this lack of members' initiatives against institutions by these members' permanency in the French architecture field, which constrains field actors through their collective routines and logics. If a field's permanent actors are those who create, maintain or break the power of its institutions, temporary actors can surf on the field's institutions and find their own trajectory - they do not create new streams of energy, but use the established frame and benefit from the existing energy.

\section{DISCUSSION AND CONCLUSION}

\subsection{Discussion}

With this paper, we aimed to shed light on how new and temporary field members react to such field's existing institutional pressures. Our results show that QSR adapted the architectural contest from the experience of its own practices to better manage the process, what we called 'surfing'. Focusing on such temporary members contributes in two ways to the neoinstitutional theory.

First, our analysis fills a void in the study of field members' behaviors to institutional pressures. Emphasizing this notion of surfing, we describe the specific practices of actors only temporarily contacted with an organizational field. Previous studies (Boxemnbaum and Rouleau, 2011; Duymedjian and Rüling, 2010; Pinkse and Kolk, 2007; Oliver, 1991) have explained how actors permanently established in a field react to institutional demands. We suggest surfing as a new answer to institutional pressures, as it resembles to neither acceptance (the temporary member questions the institution), decoupling (it does not care about appearances), defying (it does not want the field to know about its insurrection), or rule breaking (it does not aim to modify the field order or gain legitimacy over the others). 
Moreover, in contrast to institutional change (Hargrave and Van de Ven, 2006; Dacin et al., 2002; Kraatz et al., 2002), one-off, non-permanent alterations in the use of a normative institution that occur progressively do not deny that institution's structure, or even modify its predictability. Finally, surfing is not bricolage (Boxenbaum and Rouleau, 2011; Duymedjian et Ruling, 2010) because surfing, even if it combines rules several fields, does no imply any metaphysics or aim to create a new institution. Surfing thus appears as a new response for the temporary field members' challenge of reaching goals under weak institutional pressure while benefitting from them.

A second contribution of this study deals with field membership. Our focus on temporary field members offers a new perspective on organizational field membership that partly complementing existing research (DiMaggio and Powell, 1983; Phillips and Lawrence, 2000; Wooten and Hoffman, 2008) by introducing the notion of 'home' and 'host' fields. We offer a dual perception of temporary organizations' reactions to institutions: organizations who are permanent actors in a field (their 'home' field), may, at certain times, join another field (a 'host' field), for a short time. From their point of view, while they 'belong' to the host field during their interactions with its members, they play no political role in it. They mobilize their host field's existing institutions, but do not necessarily comply with their norms and values literally - rather they can adapt them to align with their own objectives.

Third, such a statement refines the role of temporary members in a field. They may first change the domination logic of central members over peripheral ones: new and temporary members gain power over permanent and central members. This implies that a new dynamism within the field may be possible from such actors. Moreover, they create a path between two organizational fields and between several logics.

\subsection{Limitations}


Our study has some limitations we want to acknowledge, especially concerning the development of the notion of "surfing" on institutions. First of all, the metaphor in itself needs a better development on several aspects, with other case studies, so as to generalize it to other contexts. Our case does not provide any clue about field permanent members' ability to surf, or about the possibility to surf on multiple institutions. Second, our study does not address the potential long-term impacts of such an answer for the field and its permanent members. We therefore cannot pronounce ourselves about the role of temporary members for the field stability or change on the long-term. Third, we focused our study of QSR on its characteristics as a temporary field member, but did not focus whether the relative power of QSR might offer another way to explain its behavior and the architects' total acceptance of the modifications it proposed. We indeed believe that if power may explain some QSR and architects' reactions, it can't be the only one. We indirectly integrated the power element thanks to Bourdieu's approach on domination within fields, but decided not to develop it.

\subsection{Implications for practice and future research}

Findings of this research exemplify the crucial role of institutions for managers and professional clients in architecture. Indeed, by acknowledging that constraining procedures can be slightly modified - if they are accepted by the other members of the field - our study shows that clients, even in a constraining environment, can have some power and negociating power. Clients should be aware of their capacity to fuel creativity in a sector that is based on it but which procedures may prevent.

We believe this study opens up several avenues for future research into institutions. First, further study of the notion of surfing (e.g., via longitudinal studies) may be interesting to identify any negative impacts it might have for organizational fields, their members and their institutions. Second, by focusing on a temporary connection to a field, this study may inspire 
further research to discover more about other characteristics of temporariness, and its longterm impacts on an organizational field. Of course, a temporary organization that lacks the power (or the desire) to change its field institutions may still initiate new ideas that become accepted by core actors and lead on to innovation within their host field. More specifically, our study suggests that more research into how institutions from one field impact those of other fields, and especially how actors not permanently connected to a field integrate and import their home field norms and values for use in their host field, could be productive. Finally, we have demonstrated how temporariness impacts normative institutions - but we also need to know where and how it might also impact regulative or cognitive institutions.

\section{NOTES}

1 Quiksilver is an international firm that represents a casual lifestyle inspired by Australian surfing culture, and Rossignol is a French ski brand, known worldwide for its innovative ski and mountain equipment.

2 Unless notes otherwise, the quotations in this paper come from committee members

3 Architectural contests are competitive mechanisms designed to facilitate the selection of an architect to design a building commissioned by a state authority, a firm or an individual. Such competitions can be open (every architect can participate to this kind of contest, by sending a architectural proposal) or by invitation (where, generally, only 4 to 6 architects are invited by the contracting owner, based on criteria such as the previous buildings they designed, and on their reputations).

4 Sketches give a general overview of the building and of its atmosphere, as well as an idea of the exterior look of the building.Technical sections detail the internal layout, to illustrate the organization and the partition of space inside the building.

5 Gabion is a construction material made of a mesh filled with rocks and wood designed to prevent landscape erosion and widely used in mountain environments.

6 It is particularly true when fields and institutions are strong and flexible enough not to be broken when being altered. 


\section{ACKNOWLEDGMENTS}

Our deep appreciation goes to: for their time and explanations, the participants of the architectural contest (the QSR direction staff and the architects Vasconi, Herault-Arnod, Arotcharen and Sud Architectes); for their precious comments and suggestions, the members of the corresponding author's $\mathrm{PhD}$ committee - Candace Jones, Isabelle Huault, Jesper Strandgaard Petersen, Hervé Laroche, Bernard Leca, Annick Valette -, the reviewers of the Academy of Management 2009 Conference, Kristian Kreiner and Kjell Tryggestad from the Center for Management Studies of the Building Process of Copenhagen Business School, the EGOS participants 2007 (session Lead Users) and 2008 (session Creative Industries), Charles Baden-Fuller and our colleagues from the Cass Business School, and Fabio Fonti from Boston College; for their ongoing support, our colleagues from the seminar Knowledge Management in Innovative Organization in Grenoble; and finally, for early discussions and her help for the field work, Severine LeLoarne from Grenoble Ecole de Management. Usual caveats apply.

\section{BIBLIOGRAPHY}

Barley, S. R., Tolbert, P. S. (1997) 'Institutionalization and Structuration: Studying the Links between Actions and Institutions', Organization Studies, 18: 93-117

Battilana, J. (2006) 'Agency and Institutions: The Enabling Role of Individuals' Social Position’, Organization, 13: 653

Berger, P. L. and Luckman, T. (1966) The Social Construction of Reality: A Treatise in the Sociology of Knowledge. Garden City, New York: Anchor Books, 51-55, 59-61

Boiral, O. (2003) 'ISO 9000: Outside the Iron Cage', Organization Science, 14 (6): 720-737

Bourdieu, P. (1988) 'Vive la Crise: For Heterodoxy in Social Science', Theory and Society, 17: 773-787

Bourdieu, P. (1990) The Logic of Practice. Cambridge: Polity

Boxenbaum, E. and Rouleau, L. (2011). "New Knowledge Products as Bricolage: Metaphors and Scripts in Organizational Theory. Academy of Management Review, 36(2), p.272-296

Chiles, T. H., Meyer, A. D., Hench, T. J. (2004) 'Organizational Emergence: The Origin and Transformation of Branson, Missouri's Musical Theater', Organization Science, 15: 499 - 519 
Dacin, M. T., Goodstein, J., Scott, W. R. (2002) 'Institutional Theory and Institutional Change: Introduction the Special Research Forum', Academy of Management Journal, 45: 45 - 57

Daly, C. (1861) L'Architecture Privée au XIXème Siècle, sous Napoléon III. Ed. De Paris

DiMaggio, P. J. and Powell, W. W. (1983) 'The Iron Cage Revisited. Institutional Isomorphism and Collective Rationality in Organizational Fields', American Sociological Review, 48: 147-160

DiMaggio, P. J., Powell, W. (1991) Introduction, in W.P Powell and P. DiMaggio (eds) The New Institutionalism in Organizational Analysis. Chicago, IL: Chicago Press University*

Duymedjian, R. and Rüling, C. (2010). 'Towards a Foundation of Bricolage in Organization and Management Theory, Organization Studies, 31(2), p.133-151

Eisenhardt, K. M. (1989) 'Building Theories form Case Study Research', Academy of Management Review, 14(4): 532 - 550

Elsbach, K. D., Sutton, I. R. (1992) 'Acquiring Organizational Legitimacy through Illegitimate Actions: A Marriage of Institutional and Impression Management Theories', Academy of Management Journal, 35 (4): 699-738

Friedland, R. (2009) 'The Endless Fields of Pierre Bourdieu', Organization 16(6): 887-917.

Garud, R., Jain, S., Kumaraswamy A. (2002) 'Institutional Entrepreneurship in the Sponsorship of Common Technological Standards: the Case of Sun Microsystems and Java', Academy of Management Journal, 45(1): 196-214

Garud, R., Hardy, C., Maguire, S. (2002) 'Institutional Entrepreneurship as Embedded Agency: An Introduction to the Special Issue', Organization Studies, 28 (7) : 957-969

Garud, R., Karnøe, P. (2003) 'Bricolage versus Breakthrough: Distributed and Embedded Agency in Technology Entrepreneurship', Research Policy, 32 (2)

Greenwood, R., Hinings, C. R. (1996) 'Understanding Radical Organizational Change: Bringing Together the Old and the New Institutionalism', Academy of Management Review, 21(4): 1022 1054

Greenwood, R., Suddaby, R. (2006) 'Institutional Entrepreneurship in Mature Fields: the Big Five Accounting Firms', Academy of Management Journal

Goodrick, E., Salancik, G. R. (1996) 'Organizational Discretion in Responding to Institutional Practices: Hospitals and Cesarean Births', Administrative Science Quarterly, 41 (1):1-28

Hargrave, T, Van de Ven, A. (2006) 'A Collective Action Model of Institutional Innovation', Academy of Management Review

Hodgson, G. M. and Jiang, S. (2007) 'The Economics of Corruption and the Corruption of Economics: An Institutional Perspective', Journal of Economic Issues, 41, 4, 1043-1061

Hoffman, A., Wooten, M. (2008) 'Organizational Fields: Past, Present and Future, in R. Greenwood, C. Oliver, K. Sahlim, R. Suddaby', The Sage Handbook of Organizational Institutionalism. London: Sage Publications.

Johnson, G., Smith, S., Codling, B. (2000) 'Microprocesses of Institutional Change in the Context of Privatization', Academy of Management Review, 25 (3): 572-585

Jones, C. (2001) 'Co-Evolution of Entrepreneurial Careers, Institutional Rules and Competitive Dynamics in American Film, 1895-1920’, Organization Studies, 22: 911-944 
Langley, A. (1999) 'Strategies for Theorizing Process Data', Academy of Management Review, 24 (4) : 691-710

Leblebici, H., Salancik, G. R., Copay, A. and King, T. (1991) 'Institutional Change and the Transformation of Organizational FFields: An Organizational History of the U.S. Radio Broadcasting Industry', Administrative Science Quarterly, 36: 333-363

Leca B. (2007) 'Closing time at the salon: the desinstitutionalization of a field configuring event at the end of the 19th century in the French art field', paper presented at a seminar, Grenoble Ecole de Management, Grenoble, France

Leca, B. Battilana, J., Boxenbaum, E. (2008) Agency And Institutions: A Review of Institutional Entrepreneurship. Working paper

Le Moniteur (2004) Paris - Les Halles, Concours 2004. Paris: Le Moniteur

Le Moniteur (2007) Organiser un Concours d'Architecture et d'Ingénierie. Paris: Le Moniteur

Merilainen, S., J. Tienari, et al. (2008) 'Hegemonic Academic Practices: Experiences of Publishing from the Periphery', Organization 15(4): 584-597.

Meyer, J. W. , Rowan, B. (1977) 'Institutionalized Organizations: Formal Structure as Myth and Ceremony', American Journal of Sociology, 83: 340-363

Oliver, C. (1991) 'Strategic Responses to Institutonal Processes', Academy of Management Review, 16(1), 145-179

Oliver, C. (1992) 'The Antecedents of Deinstitutionalization', Organization Studies, 13

Orton, J. D., Weick, E. (1990) ,Loosely Coupled Systems: A Reconceptualization', Academy of Management Review, 15 (2): 203-223

Phillips, N., Lawrence, T. B., Hardy, C. (2000) 'Inter Organizational Collaboration and the Dynamics of Institutional Fields', Journal of Management Studies, 37(1)

Pinkse, J. and Kolk, A. (2007). 'Multinational Corporations and Emissions Trading: Strategic Responses to new Institutional Constraints', European Management Journal, 25 (6), p. 441-452

Rao, H. (1994) 'The Social Construction of Reputation: Certification Contests, Legitimation, and the Survival of Organizations in the American Automobile Industry: 1895-1912', Strategic Management Journal, 15: 29-44

Rao, H., Monin P., Durand R. (2003) 'Institutional Change in Toqueville: Nouvelle Cuisine as an Identity Movement in French Gastronomy', American Journal of Sociology, 108(4): 795 - 843

Scott, W. R. (2001) Institutions and Organizations. 2nd edition. Thousand Oaks, CA: Sage

Seo, M. G. and Creed, W. E. D. (2002) 'Institutional Contradictions, Praxis and Institutional Change: A Dialectical Perspective', Academy of Management Review, 27: 222-247

Suchman, M. C. (1995) 'Managing Legitimacy: Strategic and Institutional Approaches', Academy of Management Review, 20(3): 571-610

Suddaby, R., Greenwood, R., (2002) 'Rhetorical of Legitimacy', Administrative Science Quarterly, 50: $35-67$

Whestphal, J. D., Zajac, E. J. (1994) 'Substance and Symbolism in CEOs' Long-Term Incentive Plans’, Administrative Science Quarterly, 39 (3): 367-390

Whestphal, J. D., Zajac, E. J. (2001) 'Decoupling Policy from Practice: The Case of Stock Repurchase Programs', Administrative Science Quarterly, 46: 202-228 
Winch, G., Schneider, E. (1993) 'Managing the Knowledge-Based Organization: the Case of Architectural Practice', Journal of Management Studies, 30(6)

Yin, R.K. (2003) Case Study Research, Design and Methods. 3rd Edition. Sage Publications

Zilber, T.B. (2002) 'Institutionalization as an Interplay between Actions, Meanings and Actors: the Case of a Rape Crisis Center in Israel', Academy of Management Journal, 45: 234-254

Zucker, L.G. (1977) 'The Role of Institutionalization in Cultural Persistence', American Sociological Review, 42: $726-743$ 